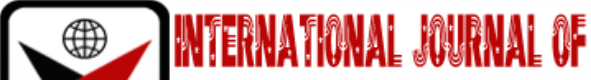

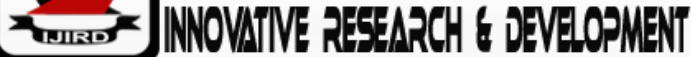

ISSN 2278-0211 (Online)

\section{Factors Affecting Road Construction Heavy Machinery Spare Part Supply Chain Performance: An Ethiopian Case}

Tesfai Habteab Tesfai
Supply Chain Manager, Docnet Medical Trading Pvt. Ltd. Co., Addis Ababa, Ethiopia
Dr. Busha Temesgen
Assistant Professor, Department of Logistics and supply chain management, Addis Ababa
University, Addis Ababa, Ethiopia

\begin{abstract}
:
Road construction, which requires heavy equipment, is one of the developing countries' leading priorities, including Ethiopia. In Ethiopia's case, this sector consumes the most prominent national budget, though challenged due to a shortage of spare parts that allow the deployed machines to work efficiently. Therefore, this study aims to assess the Factors Affecting Road Construction Heavy-Machinery SPSC performance: An Ethiopian Case. Based on the literature reviewed, the study has identified four factors that affect performance (responsiveness and efficiency): inventory level, information sharing, demand forecasting accuracy, and product pricing. A descriptive and explanatory research design was used in the study. Both quantitative and qualitative data were used in this research. For quantitative data, structured questionnaires were used. Besides, focused group discussions were conducted to collect more qualitative information. Out of 100 employees of the study organization, a sample size of 63 was taken using a stratified sampling technique. The response rate was $100 \%$. The Data were analyzed using mean, standard deviation, percentages, correlation, and regression analysis with the help of SPSS version 26 software. The study results indicated that the inventory level, information sharing, demand forecasting accuracy, and product pricing collectively impact the SPSC performance significantly. These factors collectively explain $43.6 \%$ of the SPSC performance, while the rest, $56.4 \%$, is explained by other factors which are not subject to this study, such as transportation-related and other variables mentioned in the qualitative findings. Further, the study revealed that, among the predictors (independent variables), information sharing-related characteristics have more remarkable predictive ability for SPSC performance (responsiveness and efficiency). In contrast, the other variables relating to inventory level, demand forecasting accuracy, and product price has no impact on predicting SPSC performance (responsiveness and efficiency), as far as the other variable information sharing-related factors exist. Moreover, the study recommends enhancing the quality of information sharing across SC members by employing the latest IT facilities that can enhance information sharing benefits the SPSC actors in Ethiopia. .
\end{abstract}

Keywords: Spare part, supply chain, performance, road construction, heavy- machinery, Ethiopia

\section{Introduction}

\subsection{Background}

As a developing country, Ethiopia has a strong focus on the construction industry in general and the road sector in particular. As a result, the country has allocated an outstanding national budget to the construction projects going in the country. In 2019-2020, Ethiopia allocated about 1.5 billion USD to the road sector alone, which covers about a quarter of the nation's budget, as indicated by (Cepheus Research \& Analytics, 2019).

Road construction is one of the heavy equipment-intensive sectors that principally rely on the high utilization of machinery (Day \& Benjamin, 1991). Excavators, graders, bulldozers, scrapers, loaders, tippers, dump trucks, smooth wheel rollers, pneumatic rollers, and vibratory rollers are some of the many heavy construction machines deployed in road construction activities (Prajeesh\&Sakthivel, 2016).

Perhaps, the heavy machines deployed in road construction are subjected to failure, looking for proper spare parts and maintenance. Spare parts (SP) are essential inputs required to conduct maintenance activities (AlNajjar\&Alsyouf, 2004). Furthermore, SP's are machine components that need to be replaced due to wear and tear over the equipment's operational life (Gopalakrishnan and Banerji, 2013). In addition, SP is required after the main products have been sold to customers or end-users (Wagner et al., 2012).

Further, SP customers demand long-time availability of spare parts through the whole product lifecycle of the primary product (Wagner et al., 2012). Besides, SP must be available across the supply chain (SC) to enable after-sales 
services and guarantee service to end-users (Botter and Fortuin, 2000). Therefore, a robust SC is required to make SP available and accommodate customer (end users) requirements.

The spare part supply chain (SPSC) is like any supply chain except that it solely exists to make maintenance operations run smoothly such that equipment is down for maintenance no longer than necessary (Arts, 2013). The road construction heavy machinery SP supply chain is not far from this idea; it can be defined as a network of firms supporting and strengthening heavy equipment maintenance operations to maximize equipment output.

Moreover, in the SC approach, original equipment and SP manufacturers delegate dealers to different areas of the world where their machines are expected to be sold, and the dealers play a mediation role between the end-users and the manufacturers.

In Ethiopia, there are several privately-owned spare part dealers. The study organization, My Wish Enterprise PLC (MWE PLC), is one of the non-governmental-owned SP dealers in Ethiopia. MWE PLC is an exclusive dealer of heavy machinery manufacturers such as Doosan Infracore (manufacturer of excavators, articulated dump trucks), Liugong Machinery Co., Ltd (manufacturer of Backhoe Loaders, Rollers, Forklifts, Truck Mounted Cranes, Concrete Pumps), Soosan Heavy Industries Co., Ltd (manufacturer of Hydraulic Breakers and Wagon Drill), Bobcat (manufacturer Mini Excavators), and many others.

MWE PLCcan represent similar companies (dealers) in Ethiopia's construction equipment and SP business with its diversified supply chain network.

Furthermore, it is critical to identify the factors influencing the SPSC performance of construction equipment, as it will contribute to the efficiency of national road projects and ensure the revenue of the SP supply chain actors in general. Besides, it is vital to meet the machine owner's (end users) needs ultimately.

Due to the deficiency of prior research, the study is dedicated to identifying the factors affecting Road Construction Heavy-Machinery SPSC performance in Ethiopia.

\subsubsection{Problem Definition}

Ethiopia does not manufacture branded construction machines (Pedagopu and Woldegiorgis,2018). Moreover, this designates that all the heavy road construction machinery deployed in different national road construction projects are imported with a significant foreign exchange. Hence, the machines need proper management that compensates for the expense and to meet the desired target.

Perhaps, Ethiopian scholars, including Emran Hassen A. (2017), Dagne Abebaw W. (2014), and Abdisa D. (2003), have shown that managing these national resources has been difficult due to the shortage and unavailability of SP in the supply chain, resulting in national projects risks such as cost overrun and project delays.

According to Barkawi and Partners GmbH (2002), availability is a key performance indicator in spare parts supply chain providers, indicating that the Ethiopian SPSC performs poorly, prompting further investigation into the sector.

Besides, during the preliminary assessment and discussion with senior experts in the SPSC area, the selected experts have indicated that the SPSC has problems, such as unavailability of parts, incomplete order fill rate, longer lead time, frequent backorders, lost sales, unreasonably high spare part costs due to governmental regulation, deadstock inventories as a result of the long forecast horizon, and others.

Supply Chain performance is affected by many factors, such as inventory levels, information sharing, demand forecasting, and product pricing. This study tried to empirically examine if and how these factors affect the SPSC performance from an Ethiopian context.

The study was also initiated due to a lack of prior empirical studies demonstrating how the aforementioned factors impact the SPSC of heavy road construction machinery in the Ethiopian context. With this in mind, the researchers have set out to do a case study on assessing factors affecting the SPSC performance of the heavy construction equipment dealers considering MWE PLC, as a representative of other similar companies in the construction equipment and spare part business, in Ethiopia.

This study is devoted to filling the gap by empirically finding the factors affecting the SPSC of the heavy construction machinery and opening the door to future researchers for further investigation.

\subsection{The Objective of the Study}

\subsubsection{General Objective}

The study's general objective is to assess factors affecting road construction heavy machinery SPSC Performance from an Ethiopian context.

\subsubsection{Specific Objectives}

The specific objectives of the study were:

- To assess the effect inventory level has on the performance of the Road Construction-Heavy Machinery SPSC.

- To assess the effect of information sharing on the performance of the Road Construction-Heavy Machinery SPSC.

- To assess how demand forecasting accuracy affects the performance of the Road Construction-Heavy Machinery SPSC.

- To assess how product pricing affects the performance of the Road Construction-Heavy Machinery SPSC.

\subsection{Research Questions}

This study tried to address the following research questions: 
- How does inventory level affect the Road Construction-Heavy Machinery SPSC performance?

- To what extent does information sharing affect the Road Construction-Heavy Machinery SPSC performance?

- How does demand forecasting accuracy affect the Road Construction-Heavy Machinery SPSC performance?

- How does product pricing affect the Road Construction-Heavy Machinery SPSC performance?

\section{Literature Survey}

\subsection{Supply Chain (SC)}

A SC is a network of businesses collaborating to bring goods or services to market (Lambert et al., 1998). Suppliers, production facilities, warehouses, distribution centers, and retail outlets, as well as raw materials, work-in-process inventory, and completed goods that move between the various locations, comprise the supply chain (Simchi-Levi et al,, 2008). In addition, a SCaccommodates a continuous flow of materials, information, and finance (Chopra and Meindl, 2013).

\subsection{Spare Parts (SP)}

Gopalakrishnan and Banerji (2013) describe SP as equivalent to a machine's components that require replacement due to wear and tear throughout the equipment's operational life. According to Patton and Feldmann (1997), SP is interchangeable with matching objects installed or used and may replace objects during maintenance. SP parts are required when a section of the primary product breaks. The primary product may be a vehicle, machine, or appliance for the home (DHL, 2008); in this study, the primary products are heavy construction machinery.

Moreover, SP's are items designed to ensure the continued operation of the primary product. In other words, spare parts are not required until the buyer has purchased the main product (Wagner et al., 2012).As a result, SP demand is often erratic since it is highly dependent on the equipment's use pattern and degree of maintenance (Kennedy et al., 2002). On the other hand, SP part consumers need long-term availability of SP throughout the main product's lifespan. Hence, original equipment manufacturers and their respective dealers must maintain an optimal SP level to meet customer demand and ensure the continued functioning of the equipment and machinery they sell (Hoppet al., 1997).

\subsection{Road Construction-Heavy Machinery Spare Part Supply Chain}

Generally, a supply chain is defined as a complex network of interconnected and interdependent organizations that collaborate to create and distribute items or services to the market (Tsadikovich et al., 2016).Inline, the SPSC is a network of firms, and it solely exists to ensure that maintenance activities operate smoothly and that equipment is idle for no longer than required (Arts, 2013).Similarly, the road construction heavy machinery SPSC can be defined as a network of firms supporting and strengthening the construction equipment's maintenance operations to maximize equipment output.

\subsection{Factors Affecting Supply Chain Performance}

In general, SC performance is affected by various factors, including inventory levels, information sharing, demand forecasting accuracy, and product pricing. This study will assess the theories behind these factors.

\subsubsection{Inventory Level Related Factors}

An inventory is an idle asset stored in various forms for current and future usage (selling or distribution)(Hokey Min, 2015).Inventory is a massive expense throughout the supply chain, but it also significantly impacts responsiveness and efficiency. Due to the high cost associated with inventory, supply chain managers' primary priority is to reduce inventory without raising expenses or losing responsiveness (Guajardo et al., 2012).

Maintaining adequate inventory levels at each step of the chain necessitates good inventory management. According to Kotler P. (2002), inventory management encompasses all operations involved in establishing and controlling inventory levels and ensures appropriate supply and a low degree of over-or under-stocking.The primary goal of inventory management is to reduce overall costs to assure profitable operations (efficiency) and optimize customer service, which is defined as responsiveness to the customer(Oluwaseyi J. et al., 2017). Additionally, supply chain players must use different approaches that lower operating costs while improving SC performance (Oluwaseyet al., 2017).

Businesses use various inventory management models and strategies to determine inventory levels that balance responsiveness and efficiency. Some of the techniques are discussed below.

\subsubsection{Economic Order Quantity (EOQ)}

An EOQ is the best order quantity that minimizes total yearly inventory costs and provides guidance on how much and when to refill inventory (Hokey Min, 2015). In addition, EOQ improves performance by ensuring that supplies are delivered to the organization within the specified time frame; this decreases the lead time or waiting time (Evelineet al., 2019). The ordering cost, cheapest deliverer advantage, and others are benefits of EOQ that impact efficiency.

\subsubsection{Vendor-Managed Inventory (VMI)}

In VMI, the supplier owns the inventory and is responsible for its management, including the financial burden of keeping inventory(Hokey Min, 2015). In return for the added expense of inventory management, the vendor is often compensated with expanded or more reliable business prospects. The customer that utilizes VMI receives a variety of advantages, such as higher inventory turnover and sales, more excellent order fill rates, enhanced customer service, shorter lead times, more significant cash flows, reduced liabilities, and a better inventory level based on actual customer 
sales (Hokey Min, 2015). Enhanced sales volume obtained from VMI leads to better efficiency, whereas VMI characteristics such as higher-order fill rates, enhanced customer service, and shorter lead times result in increased customer response.

\subsubsection{Just-In-Time (JIT)}

Heizer, Render, and Munson (2017) defined JIT as delivering an exact quantity of inventory products at the required time. Thus, the JIT approach improves the efficiency of the business and reduces waste, which results in a drop in inventory costs since goods will come just as required (Heizer, Render, and Munson, 2017). Furthermore, JIT is often regarded as the most crucial component of reducing inventory levels and cutting inventory holding costs (Phung, 2011). Thus, the advantages of JIT include minimizing inventory costs (efficiency) and ensuring that items are accessible when needed (responsiveness).

\subsubsection{Information Sharing Related Factors}

Information Sharing (IS) refers to exchanging crucial and exclusive information with distribution partners (Mendes et al., 2012). Numerous scholars have shown the relationship between IS and supply chain performance. For example, according to Ajay \&Maharaj (2010), IS significantly reduces the total cost of operating a successful SC and enhances the holistic management of SC operations. IS enhances SC performance in various ways; it improves service levels, customer response, cost savings, and complexity reduction (Flynn et al., 2010). As a result, the SC would perform better in terms of financial returns, service quality, and time spent doing tasks (Sheikhiet al,2018).

Further, IS enables businesses to swiftly procure customized items and understand customers' changing tastes and preferences (George and Madhusudanan Pillai, 2019). Moreover, adequate information flow in the supply chain results in product enhancement, reduced customer response times, and cost savings or efficiency (Paulraj and Chen, 2007).A few IS dimensions are discussed below.

\subsubsection{Quality of Information Sharing}

The quality of IS encompasses factors such as the correctness, timeliness, sufficiency, and reliability of the data provided (Moberget al., 2002). Researchers have examined the effect of information quality on firm performance and discovered a strong correlation between enhanced information quality and increased organizational performance (Viveket al., 2009). Furthermore, better organizational performance would mean better SC performance.

\subsubsection{Level of Information Sharing}

The level of IS refers to the extent to which critical and proprietary information is communicated to one's supply chain.

According to Seidmann and Sundararajan (1998), enterprises should disclose information only to the extent that it benefits them. For instance, communicating order status may help enhance customer service and save on human resources expenses. In addition, sharing retail sales data may help lessen the bullwhip effect, leading to the belief that a high degree of information results in a responsive and efficient supply chain.

\subsubsection{Information Technology (IT)}

IT enables the exchange of information between multiple entities (Brandon et al., 2006). As a result, SC performance is boosted by IS (Salcedo and Grackin, 2000). In general, IT enables a reduction in cycle time, a decrease in inventory, a reduction in the bullwhip effect, an increase in the effectiveness of distribution channels, and ultimately aids in the development of responsiveness, resilience, reliability, and realignment necessary for developing a customer-focused SC strategy (Madhani, P. M., 2017). As a result, IT plays a critical role in the responsiveness and efficiency of a SC.

\subsubsection{Demand Forecasting Accuracy-Related Factors}

Forecasting is described as creating predictions from historical and current data, most often via trend analysis(Sunil Chopra and Meindl, 2007).An accurate forecast is a first and most crucial step in successfully managing a SC (Singh, 2014). Thus, a good forecasting approach reduces the variance between actual and predicted demand (Joel D. et al., 2012).Furthermore, forecast accuracy significantly impacts SC performance, such as inventory cost, backorder cost, lost sales, and customer goodwill (George and Madhusudanan Pillai, 2019).Therefore, forecasting is a vital aspect in determining the overall success of the SC(Zhao \&Xie, 2002 and Traperoet al., 2011). Moreover, forecasting demand accurately leads to fewer inventories, fewer stock-outs, better production schedules, cost savings, and more excellent customer service(Joel D. et al., 2012).On the other hand, forecasting errors are connected with high supply chain costs, such as missed sales, unneeded safety stock, dissatisfied customers, and loss of goodwill (Donald J. et al., 2002). Besides, an erroneous estimate leads to a company's resources being underutilized (Shang et al., 2004).

Moreover, forecast accuracy is dependent on several elements, including those stated below;

\subsubsection{Time Horizon}

The forecast horizon is the number of periods beyond the recognized data for which projections are made (Lewis, 2000). Forecast horizons can be long or short; long-term projections can range from three to ten years, while short-term projections can range from one to three months (Korpela J. et al., 1996). Besides, most scholars believe that the longer the forecasting horizon, the less forecast accuracy (Schnaars, 1984), and the shorter the horizon is associated with better SC performance responsiveness and efficiency. 


\subsubsection{Data Availability}

More precise forecasting is achievable when more data is provided (Chambers, Mullick, and Smith, 1971 and Michael, 1979). The more data available, the more accurate forecasts will be, and fewer inventory costs characterize the better SC performance, fewer backorder costs, reduced missed sales costs, and more customer goodwill (Steven P., 1984).

\subsubsection{Human factors and tools and systems}

The forecaster is the process's leader(Singh, 2014). Hence, the forecaster must have a robust set of skills and competencies to make the necessary adjustments and judgments.Forecasters must manage the data generated by forecasting tools and systems, including its meanings, validity, and interpretation (Singh, 2014).Besides, tools and systems allow storing and sharing a massive quantity of information, allowing for quick and sophisticated analysis, and generating predictions more effectively. Computers and software can do a far better job of processing many data than a person can.When underutilized technologies (tools) and processes impede accuracy, they may be worthless or misleading (Morlidge, 2014). Therefore, the more the forecaster can appropriately deploy forecasting tools and systems, the better forecast accuracy and thus better SC chain performance.

\subsubsection{Product Pricing Related Factors}

Pricing is how a business determines the price at which it will sell its products and services to customers (Chopra and Meindl, 2013). Besides, Hugos (2011) asserts that pricing affects a firm's sales and gross profit and that profitability will mean efficiency, one way or the other. According to Chopra and Meindl (2013), pricing, on the other hand, plays a significant role in meeting specific customer segments that can purchase the product and their expectations, and meeting specific customers' expectations would lead to mean responsiveness.

According to Chopra and Meindl (2013), the following components of price choices that impact SC performance are crucial.

\subsubsection{Pricing and Economies of Scale}

The majority of SC operations benefit from economies of scale. (Chopra and Meindl, 2013). Inline, to take advantage of economies of scale, many businesses choose to purchase every quarter to accrue big enough orders for bulk buying or freight consolidation (Hokey Min, 2015). According to Chopra and Meindl (2013), changeovers make shorter manufacturing runs more costly per unit than big production runs, while loading and unloading expenses make delivering a truckload to one place less costly than delivering it to four. These cost implications are examples of an inefficient supply chain. The examples here show how to use economies of scale in their product pricing system.Increased sales due to quantity discounts generate profit for the business, while reduced costs (for example, in manufacturing and transportation) resulting from economies of scale result in increased customer satisfaction (responsiveness).

\subsubsection{Everyday Low Pricing Versus High-Low Pricing}

According to Chopra and Meindl (2013), certain firms employ an everyday low pricing strategy, maintaining stable prices over time. Such businesses do not offer discounts on their products to maintain their daily low pricing strategy. In comparison, most supermarkets and other seasonal product retailers employ a high-low product pricing strategy and periodically offer steep discounts on a subset of their products. Daily low prices result in relatively stable demand (Chopra and Meindl, 2013). However, the high-low pricing strategy results in a peak in demand during the discount period, which is frequently followed by a sharp decline in demand during the subsequent discount exemption period. Thus, both approaches enable the firm to meet various customer requirements (meaning be responsive) while also ensuring the firm's profitability by securing sufficient sales to meet customer needs.

\subsubsection{Fixed Price versus Menu Pricing}

A business must determine whether to charge a flat rate (fixed price) for supply chain operations or provide a menu of rates that change according to other attributes, such as response time or delivery location(Chopra and Meindl, 2013).

If consumer value varies greatly across specific qualities, a price menu is often viable; and these tactics are customer-centric, which means they are responsive (Chopra and Meindl, 2013).

\subsection{SPSC Performance Measurement (Responsiveness and Efficiency)}

Performance measurement is often described as the process of assessing efficiency and effectiveness(Neely et al., 1995). Mentzer (1991) stated that effectiveness is about how many objectives are realized. According to Beamon (1999), efficiency measures how well a firm's resources are optimized.

Concerning SPSC performance measurement methods, a few studies have been conducted. Among the many studies, Barkawi and Partners GmbH (2002) indicated that stock availability,on-time delivery performance, order fill rate, number of backorders, failure rate, the average cost per event, cycle time, and accuracy of delivery are fundamental SPSC performance measurement metrics. On the other hand, according to Achetouiet al. (2019), the metrics mentioned by scholars, including Barkawi and Partners GmbH (2002), focus on customer expectations about service quality and alternative ways to assess SPSC performance is essential.

Following earlier research suggestions to consider additional dimensions for SPSC performance, this research utilized what Hugos (2011) provided to quantify supply chain performance using two characteristics: responsiveness and efficiency. 
A responsive supply chain focuses on the speed at which a supply chain offers items to customers (Bolstorff and Rosenbaum, 2012). A responsive supply chain quickly reacts to market demand, but it costs more due to larger batch sizes (Skinner, 1974). On the other hand, efficiency determines the extent to which resources are utilized (Lai et al., 2002). Thus, an efficient supply chain lowers unit costs but frequently sacrifices market responsiveness (Skinner 1974).

1. Responsiveness related metrics

Fill Rate: the percentage of units ordered shipped in a given order is referred to as the fill rate; alternatively, the fill rate can be defined as measures the actual fill rate that is compared with the target fill rate.

Product lateness: the time elapsed between the promised time and the actual product delivery date. Product lateness measures the delivery date minus the due date.

Customer response time: The amount of time between an order being made and its corresponding delivery; this measures the difference between the time an order is made and its corresponding delivery.

Lead time: The total amount of time required to produce a particular item or service. Moreover, this measures the total amount of time required to complete one unit of product or service.

Customer complaints: Registered complaints from customers about products or services. Customer complaints measure the total number of complaints registered.

Shipping errors: wrong product shipments; this measures the percentage of wrong shipments

2. Efficiency related metrics

Production costs/distribution costs: combined costs of raw materials and labor in producing goods/combined costs of distribution, including transportation and handling costs; it measures the sum of the total costs of inputs used to produce output/services (fixed and variable costs).

Transaction costs: The costs other than the price that is incurred in trading goods or services (e.g., searching costs, negotiation costs, and enforcement costs); this measures the sum of searching costs (the costs of locating information about opportunities for exchange), negotiation costs (costs of negotiating the terms of the exchange), and enforcement costs (costs of enforcing the contract).

Profit: The positive gain from an investment or business operation after subtracting all expenses, which measures total revenue deducting the expenses.

Return on investments: a measure of a firm's profitability and how effectively it uses its capital to generate profit. This ratio compares net profit to total assets.

Table 1: Metrics for Responsiveness and Efficiency

Source: (Beamon1999; Aramyan Et Al., 2007)

\section{Methodology / Approach}

\subsection{Description of the Study Area}

The study was done based on data collected from private-owned major heavy-duty equipment and SP dealer located in Addis Ababa, the capital city of Ethiopian named MWE PLC that was takenas a representative of different dealers as it has diversified SC and has stayed in the SP business for over 15 years. In addition, the case study organization has been serving as a delegate for many spare part manufacturers, providing the construction sector with the most comprehensive range of integrated solutions for the supply, sales, buying, and leasing of new machines, engines, and authentic spare parts. Figure 1 below briefly shows the SC network of the dealer.

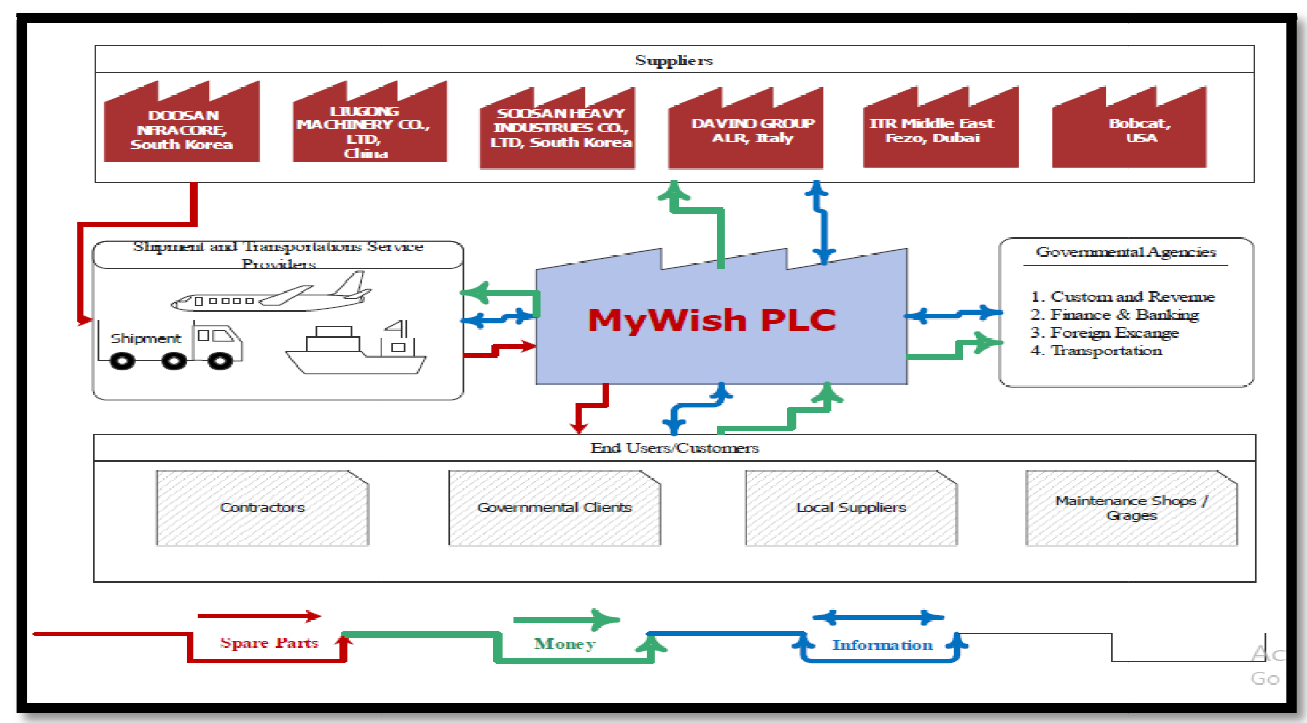

Figure 1: Supply Chain Network of the Study Organization Source: Based on a Survey at MWE PLC SC Network

\subsection{Variables of the Study and Conceptual Framework.}

The study has both dependent and independent variables. The independent variables are; inventory level-related factors, information sharing-related factors, demand forecasting accuracy-related factors, and product pricing relatedfactors. The dependent variable is SPSC performance measured in terms of responsiveness and efficiency. The conceptual framework is depicted in figure 2 below. 


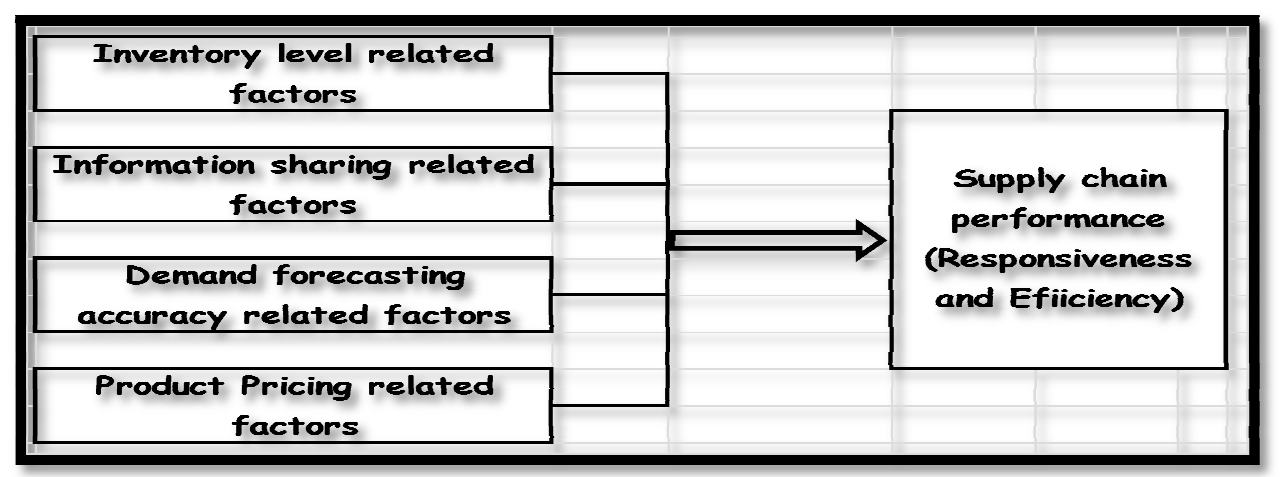

Figure 2: Conceptual Framework Own Survey Based on

Different Kinds of Literature

Source: Researchers'Own

\subsection{Research Approach}

The study used a mixed approach to identify the variables that affect road construction - heavy machinery SP supply chain performance. The mixed approach helped triangulate the study's qualitative and quantitative data, which aligns with the concept described by (Saunders et al., 2007).

\subsection{Research Design}

Design-wise, the study deployed descriptive and explanatory designs. Descriptive research, according to Kothari (2004), comprises several types of surveys and fact-finding inquiries. Descriptive research enables the researcher to gather data on the present state of the phenomenon and characterize 'what exists' in terms of factors such as inventory level, information sharing, demand forecasting accuracy, and price. Further, the explanatory research design was chosen because it stresses why questions as stated by (Cooper and Schindler, 2014), and the investigation would establish causal explanations between the dependent and independent variables by addressing the why questions.

\subsection{Population and Sampling Design}

All personnel in the company who have direct relationships with the spare parts supply chain, such as those working in sales, stores, marketing, import and export department staff, service (after-sales service department), and the parts department, are included in the study's population. In this regard, the target population was 100 people. Again, a formula described byKothari (2004) indicated below was used to determine the sample size, and the sample size was calculated to be 63 .

$$
n=\frac{z^{2} \cdot p \cdot q \cdot N}{e^{2}(N-1)+z^{2} \cdot p \cdot q}
$$

\subsection{Data Collection and Data Analysis}

Further, the researchers gathered both primary and secondary data in order to acquire reliable data. The primary data for this research was gathered from workers, supervisors, and managers at the targeted businesses. A questionnaire with closed-ended items involving a five-point Likert scale and focus group discussions were utilized to gather primary data in this research, and this is in line with Askia (1999), who indicates that, for survey research, structured questionnaires are the most suitable data collecting tool. In addition, secondary data was gathered from academic publications, organizational reports, and manuals from documentary sources.

Finally, both descriptive (mean, standard deviation, and percentages) and inferential statistical methods (multiple regression) were used to analyze the collected data using the Statistical Package for the Social Sciences (SPSS) version 26.0 .

Correlation and multiple regression analysis were used to determine the degree and direction of the relationship between the independent and dependent variables. Specifically, multiple regression was used to identify the factors affecting the SPSC performance as measured by responsiveness and efficiency.

\subsection{Reliability Analysis}

The instrument was pilot-tested, reviewed by subject matter experts and practitioners to ensure validity. The Chronbach alpha coefficient is the most often used method in the literature for assessing the scale's reliability and stability. The Cronbach's alpha coefficient should be higher than 0.7, according to Andy (2006). The alpha value of each variable in the research, individually and collectively, is higher than 0.7 , which is considered acceptable. 


\begin{tabular}{|c|c|c|c|}
\hline \multicolumn{4}{|c|}{ Reliability Statistics } \\
\hline S.no & Variable & Cronbach's Alpha & No. of Items \\
\hline 1 & Inventory level related factors & 0.786 & $\mathbf{7}$ \\
\hline 2 & Information sharing relate factors & 0.818 & 6 \\
\hline 3 & Forecast accuracy-related factors & 0.720 & 7 \\
\hline 4 & Price related factors & 0.727 & 6 \\
\hline 5 & Responsiveness related statements & 0.797 & 5 \\
\hline 6 & Efficiency related statement & 0.756 & 4 \\
\hline
\end{tabular}

Table 2: Source: Reliability of Variables

Source: SPSS Output of Survey, 2021

\section{Results \& Discussion}

\subsection{Result of the Descriptive Statics}

The study found 63 respondents, approximately 76\%, had more than four years of work experience in the organization. Furthermore, the educational background of the respondents reveals that the majority of them (about 96.8\%) are well educated, with first-degree graduates or higher.

In the descriptive analysis, the mean score of both the independent and dependent variables was analyzed. Accordingly, the inventory level-related factors, information sharing-related factors, forecast accuracy-related factors, and product pricing-related have a mean score of greater than 2.32, 2.86, 2.17, and 2.49, respectively. Moreover, the dependent variables of performance responsiveness and efficiency have a mean score greater than 2.84 and 2.8, respectively. Therefore, the descriptive analysis concludes that the respondents agree with the statements indicated for both the independent and dependent variables. The mean values were interpreted as strong disagreement if $<1.50$, as disagreement if between 1.51 and 2.50, as neutral if between 2.51 and 3.50, as agreement if between 3.51 and 4.50, and as strong agreement if above 4.51 following Al-Sayaad, Rabea, and Samrah (2006) mean score calculated from five-point Likert-scale.

\begin{tabular}{|c|c|c|}
\hline S.no & Variables & Grand Mean \\
\hline 1 & Inventory related factors & 2.67 \\
\hline 2 & Information sharing related factors & 3.10 \\
\hline 3 & Forecast accuracy-related factors & 2.66 \\
\hline 4 & Pricing related factors & 2.65 \\
\hline 5 & Responsiveness related factors & 2.52 \\
\hline 6 & Efficiency related factors & 3.02 \\
\hline & Overall Grand Mean & 2.77 \\
\hline
\end{tabular}

Table 3: Grand Mean of Variables

\subsection{Result of the Qualitative Study}

Experts in the SPSC area were selected for focus group discussion and asked to brief the researchers about their opinions and understanding of the factors affecting their spare parts supply chain performance. Accordingly, the experts said that the inventory level, information sharing between actors, forecast accuracy, and product pricing issues are crucial elements that affect their company's SPSC performance.

Further, the respondents explain that other supply chain factors such as transport, reverse logistics (re-exporting parts to the supplier), the government's spare part cost estimation trend, and spare part production-related issues affect the SPSC's performance in addition to the factors mentioned earlier.

The experts say that since the government dominates the sea and inland transport, there is no chance for the private sector to get involved in the transportation process. The Ethiopian regulation obligates using the Ethiopian shipping agency transport service, no other alternative. This uncompetitive practice in the multimodal transport system monopolized by the Ethiopian shipping agency has affected the lead time, resulting in non-responsive SC.

Besides, when it happens, and there is a need to send back parts (as a kind of reverse logistics or re-exporting), due to defect or further modification and innovative work by the suppliers, it is difficult to do so as the country's regulations do not permit doing so. As a result, a significant amount of inventory is accumulated in the company warehouse, affecting the company's efficiency.

Another worry of the respondents was how the government re-evaluated the cost of imported spare parts. Usually, dealers such as MWE PLC have a discount privilege due to bulk purchases from suppliers. However, if the government suspects the cost as if the invoices of the imported goods are understated, the government re-evaluates the spare part costs and imposes a charge on the parts, resulting in the extra cost of the parts being imported. As a result, the cost directly or indirectly goes to the end-users, affecting the company's pricing system in particular and the spare part supply chain in general, affecting the responsiveness of the dealers.

Moreover, the experts raised an issue concerning in-house spare parts production. Recalling Pedagopu and Woldegiorgis (2018) idea that Ethiopia does not manufacture branded construction machines, the experts witnessed that the availability of in-house production firms would have minimized production costs, transaction costs, and transportation costs, and that would have enabled the SPSC of MWE PLC to be more responsive and efficient. 


\subsection{Result of Correlation Analysis}

Under correlation analysis, as portrayed in the table below, the performance of the heavy construction SPSC is positively related to all variables. Moreover, concerning the strength of the relation, performance of the heavy construction SPSC is strongly correlated with inventory levels-related factors and forecast accuracy-related factors, with Pearson's correlation coefficients ( $\mathrm{r}$ ) of 0.541 and 0.565 , respectively, and the variables associated with information sharing and price show a modest relation with performance with Pearson's correlation coefficient (r) values of 0.474 and 0.455 , respectively.

\begin{tabular}{|c|c|c|c|c|c|c|}
\hline \multicolumn{7}{|c|}{ Correlations $^{\mathbf{b}}$} \\
\hline \multicolumn{2}{|c|}{ Variables } & \multirow{2}{*}{$\begin{array}{c}\begin{array}{c}\text { Inventory } \\
\text { Related } \\
\text { Factors }\end{array} \\
1\end{array}$} & \multirow{2}{*}{$\begin{array}{c}\text { Information } \\
\text { Sharing } \\
\text { Related } \\
\end{array}$} & \multirow{2}{*}{$\begin{array}{c}\text { Forecast } \\
\text { Accuracy- } \\
\text { Related } \\
\end{array}$} & \multirow{2}{*}{$\begin{array}{l}\text { Pricing } \\
\text { Related } \\
\text { Factors } \\
\end{array}$} & \multirow{2}{*}{$\begin{array}{l}\text { Responsiveness } \\
\text { And Efficiency }\end{array}$} \\
\hline $\begin{array}{l}\text { Inventory related } \\
\text { factors }\end{array}$ & $\begin{array}{c}\text { Pearson } \\
\text { Correlation } \\
\end{array}$ & & & & & \\
\hline & Sig. (2-tailed) & & & & & \\
\hline \multirow[t]{2}{*}{$\begin{array}{c}\text { Information } \\
\text { sharing related }\end{array}$} & $\begin{array}{c}\text { Pearson } \\
\text { Correlation }\end{array}$ & $.592^{* *}$ & 1 & & & \\
\hline & Sig. (2-tailed) & 0 & & & & \\
\hline \multirow[t]{2}{*}{$\begin{array}{c}\text { Forecast } \\
\text { accuracy-related }\end{array}$} & $\begin{array}{l}\text { Pearson } \\
\text { Correlation }\end{array}$ & $.670^{* *}$ & $.361^{* *}$ & 1 & & \\
\hline & Sig. (2-tailed) & 0 & 0.004 & & & \\
\hline \multirow[t]{2}{*}{$\begin{array}{l}\text { Pricing related } \\
\text { factors }\end{array}$} & $\begin{array}{c}\text { Pearson } \\
\text { Correlation }\end{array}$ & $.472^{* *}$ & 0.114 & $.633^{* *}$ & 1 & \\
\hline & Sig. (2-tailed) & 0 & 0.372 & 0 & & \\
\hline \multirow[t]{2}{*}{$\begin{array}{l}\text { Responsiveness } \\
\text { and efficiency }\end{array}$} & $\begin{array}{c}\text { Pearson } \\
\text { Correlation } \\
\end{array}$ & $.541^{* *}$ & $.474^{* *}$ & $.565^{* *}$ & $.455^{* *}$ & 1 \\
\hline & Sig. (2-tailed) & 0 & 0 & 0 & 0 & \\
\hline \multicolumn{7}{|c|}{${ }^{* *}$. Correlation is significant at the 0.01 level (2-tailed). } \\
\hline
\end{tabular}

Table 4: Result of Correlation Analysis

Source: Correlation Analysis (SPSS Output), 2021

\subsection{From the Model Summary}

From the model summary, the R-squared (Coefficient of Determination) statistic indicates the percentage of variation in the dependent variable explained by the independent variables. Besides, the preceding model shows that the $\mathrm{R}$ square value of 0.436 (43.6\%) indicates a strong relationship between all predictors and the dependent variable. Alternatively, we may state that the predictors collectively account for 0.436 (43.6\%) of the dependent variable. The remaining $56.4 \%$ is allocated to other supply chain concepts and practices not covered by this scheme, such as transportation and warehouse management.

\begin{tabular}{|c|c|c|c|c|}
\hline \multicolumn{5}{|c|}{ Model Summary $^{\mathbf{b}}$} \\
\hline Model & R & R Square & Adjusted R Square & Std. Error of the Estimate \\
\hline 1 & $.660^{\mathrm{a}}$ & 0.436 & 0.397 & 4.35510 \\
\hline a. Predictors: (Constant), Pricing related factors, Information sharing related, Forecast accuracy-related, Inventory \\
related factors \\
b. Dependent Variable: Responsiveness and efficiency \\
\hline
\end{tabular}

Table 5: Model Summary

Source: SPSS Output Survey, 2021

\subsection{From regression Coefficients}

\begin{tabular}{|c|c|c|c|c|c|c|}
\hline \multicolumn{7}{|c|}{ Coefficients $^{a}$} \\
\hline \multirow{2}{*}{\multicolumn{2}{|c|}{ Model }} & \multicolumn{2}{|c|}{ Unstandardized Coefficients } & \multirow{2}{*}{$\begin{array}{c}\text { Standardized Coefficients } \\
\text { Beta } \\
\end{array}$} & \multirow[t]{2}{*}{$\mathbf{t}$} & \multirow[t]{2}{*}{ Sig. } \\
\hline & & B & Std. Error & & & \\
\hline \multirow[t]{5}{*}{1} & (Constant) & 0.729 & 3.663 & & 0.199 & 0.843 \\
\hline & Inventory related factors & 0.111 & 0.213 & 0.081 & 0.520 & 0.605 \\
\hline & $\begin{array}{c}\text { Information sharing } \\
\text { related }\end{array}$ & 0.516 & 0.212 & 0.306 & 2.430 & 0.018 \\
\hline & Forecast accuracy-related & 0.414 & 0.238 & 0.264 & 1.739 & 0.087 \\
\hline & Pricing related factors & 0.363 & 0.223 & 0.214 & 1.631 & 0.108 \\
\hline & & Depende & e: Responsi & and efficiency & & \\
\hline
\end{tabular}

Table 6: Regression Coefficients of the Study

Source: SPSS Output Survey, 2021 
In the regression analysis, among the other predictors (independent variables), information sharing-related factors with a significance value of 0.018 are statistically significant in predicting performance (responsiveness and efficiency) since their p-values are less than 0.05 .

However, the p-values for Inventory-related factors (P. value of 0.605), Forecast accuracy-related factors (P. value of 0.087), and Product pricing-related factors (P. value of 0.108 ) are greater than the alpha level of 0.05 , indicating that they are not statistically significant. Thus, changes in these variables are not associated with changes in the dependent variable (responsiveness and efficiency), as far as the other variable information sharing-related factors exist.

\section{Conclusion and Recommendation}

The following conclusions are made in light of the above findings.

Based on the descriptive analysis, the study concludes; all factors (inventory-related factors, information-sharing-related factors, forecast accuracy-related factors, and pricing-related factors) have affected performance.

According to the Correlation analysis, all variables have a positive relationship with performance. Inventoryrelated and forecast accuracy-related factors have a positive and strong relationship with performance (responsiveness and efficiency), whereas variables relating to information sharing and price have a good and modest relationship with performance (responsiveness and efficiency).

The research found that, among the other predictors (independent variables), information sharing-related factors had a more remarkable predictive ability for MWE PLC performance (responsiveness and efficiency).In contrast, the other variables have no significant impact on the study organization's SPSC performance (responsiveness and efficiency), as far as the other variable information sharing-related factors exist.

Thus, MWE PLC and other SPSC actors can benefit from enhancing information sharing across SC members by employing the latest IT facilities that enablereal-time information sharing.

\section{Future Scope}

This study was designed to analyze factors affecting road construction-heavy machinery SPSC performance: An Ethiopian case, taking MWE PLC as a representative. Perhaps, MWE PLC, Ethiopia, is a single company in the spare part business and, hence, it would be better if future researchers included respondents from different stakeholders, which may provide a better result. Moreover, many prior researches has conducted sufficient surveys on spare part inventory management models. However, none have studied factors influencing spare part supply chain performance, which is the main limitation of prior research.

Hence, future researchers should include other variables and better sample sizes that might affect the SPSC performance.

\section{References}

i. Abdissa D. (2003). Claims in Ethiopian Construction Industry. Addis Ababa, Ethiopia. Retrieved from http://etd.aau.edu.et/handle/123456789/80/recent-submissions.

ii. Achetoui, Z., Mabrouki, C., \& Mousrij, A. (2019). A review of spare parts supply chain management. Jurnal Sistem Dan Manajemen Industri, 3(2), 67. https://doi.org/10.30656/jsmi.v3i2.1524

iii. Ajayi, N., \& Maharaj, M. (2010). Effects of Information Sharing within Supply Chains. Academia, 35-42(Pretoria: University of Pretoria.), 2010.

http://www.academia.edu/467536/Effects_of_Information_Sharing_within_Supply_Chains

iv. Al-Najjar, B., \& Alsyouf, I. (2004). Enhancing a company's profitability and competitiveness using integrated vibration-based maintenance: A case study. European Journal of Operational Research, 157(3), 643-657. https://doi.org/10.1016/S0377-2217(03)00258-3

v. Al-Sayaad, J., Rabea, A., Samrah, A. (2006). Statistics for Economics Administration Studies. Jeddah: Dar Hafez

vi. Andy Fild. (2006). Discovering statistics using SPSS (2ndedn). London: SAGE Publications.

vii. Aramyan, L. H., Lansink, A. G. J. M. O., Van Der Vorst, J. G. A. J., \& Kooten, 0. Van. (2007). Performance measurement in agri-food supply chains: A case study. Supply Chain Management, 12(4), 304-315. https://doi.org/10.1108/13598540710759826

viii. Arts, J. J. (2014). Spare parts planning and control for maintenance operations. In Civil-Comp Proceedings (Vol. 104, Issue 2013). https://doi.org/10.4203/ccp.104.301

ix. Asika, N. (1999). Research methodology in the Behavioural Science. Ikeja: Longman Nigeria Plc

x. Barkawi and Partners GmbH. (2002) 'Global Study on Spare Parts Logistics', Munich.

xi. Beamon, B. M. (1999). Measuring supply chain performance. International Journal of Operations and Production Management, 19(3), 275-292. https://doi.org/10.1108/01443579910249714

xii. Bolstorff, P. and Rosenbaum, R. (2012). Supply Chain Excellence - A Handbook for Dramatic Improvement Using the SCOR Model (3rd Edition).

xiii. Botter, R., \& Fortuin, L. (2000). Stocking strategy for service parts - A case study. International Journal of Operations and Production Management, 20(6), 656-674. https://doi.org/10.1108/01443570010321612

xiv. Brandon M., Howe, A., Dagley, V., Salter, C. and Warren, C. (2006). What appears to be helping or hindering practitioners in implementing the common assessment framework and lead professional working.Child Abuse Review, Vol. 15

xv. Cepheus Research \& Analytics. (2019, July 10). Ethiopia's 2019-20 Budgets. Macro Research Ethiopia 
xvi. Chambers, J. C., S. K. Mullick, and D. D. Smith. (1971). 'How to Choose the Right Forecasting Technique,'Harvard Business Review, 49 (July-August), 45-71.

xvii. Chopra, S. \&Meindl, P. (2007). Supply chain management: strategy, planning, and operation (3rded.). United States of America.: Pearson Education

xviii. Chopra, S. \&Meindl, P. (2013). Supply chain management: strategy, planning, and operation (5 ${ }^{\text {th }}$ ed.). United States of America.: Pearson Education

xix. D.Lewis, C. (2000). Demand Forecasting and Inventory Control. A computer aided learning approachWoodhead Pub. in association with the Institute of Operations Management.

xx. Dagne, Abebaw W.(2014). Loss Assessment Of Construction Equipment Productivity And Its Impact On Equipment Financial Performance In Federal Road Projects: A Case Study On, Three Federal Asphalt Road Projects In SNNPR, Addis Ababa, Ethiopia. Retrieved from http://etd.aau.edu.et/handle/123456789/80/recent-submissions.

xxi. Day D. A., \& Benjamin, N. B. H. (1991). Construction equipment guide. Choice Reviews Online, 29(04), 29-212229-2122. https://doi.org/10.5860/choice.29-212

xxii. DHL, (2008). DHL Logbook - in cooperation with Technical University Darmstadt. [Online]

xxiii. Donald J. Bowersox, David J. Closs, M. Bixby Cooper. (2002). Supply Chain Logistics Management. New York, NY: McGraw-Hill/ Irwin

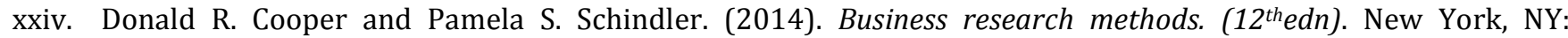
McGraw-Hill/Irwin.

xxv. Emran, Hassen A. (2017). A Study on Development of a Conceptual Risk Management Framework: A Case Study on Addis Ababa City Roads Authority. Addis Ababa, Ethiopia. Retrieved from http://etd.aau.edu.et/handle/123456789/80/recent-submissions.

xxvi. Eveline, C., Kitheka, S., Charles, C., James, O., \& Abeid, T. (2019). Effects of Inventory Management Techniques on Procurement Performance: An Empirical Study. International Journal of Innovative Research and Development, 8(8). https://doi.org/10.24940/ijird/2019/v8/i8/aug19072

xxvii. Flynn, B. B., Huo, B., \& Zhao, X. (2010). The impact of supply chain integration on performance: A contingency and configuration approach. Journal of Operations Management, 28(1), 58-71. https://doi.org/10.1016/j.jom.2009.06.001

xxviii. George, J., \& Madhusudanan Pillai, V. (2019). A study of factors affecting supply chain performance. Journal of Physics: Conference Series, 1355(1). https://doi.org/10.1088/1742-6596/1355/1/012018

xxix. Gopalakrishnan, P., \& Banerji, A. K. (2013). Maintenance and Spare Parts Management. 400. https://books.google.com/books?id=FZ0LudKUcJgC\&pgis=1

xxx. Guajardo, M., Rönnqvist, M., Halvorsen, A. M., \& Kallevik, S. I. (2015). Inventory management of spare parts in an energy company. Journal of the Operational Research Society, 66(2), 331-341.

https://doi.org/10.1057/jors.2014.8

xxxi. Heizer, J., Render, B. and Munson, C. (2017). Operations Management Sustainability and Supply Chain Management. (12 ${ }^{\text {th }}$ ed). United States of America.: Pearson Education

xxxii. Hokey Min. (2015). The Essentials of Supply Chain Management. Bowling Green State University: Paul Boger.

xxxiii. Hopp, W. J., Spearman, M. L., \& Zhang, R. Q. (1997). Easily implementable inventory control policies. Operations Research, 45(3), 327-340. https://doi.org/10.1287/opre.45.3.327

xxxiv. Hugoss, M.H. (2011). Essentials of supply chain management, (3 ${ }^{\text {rd }}$ ed.). New Jersey: John Wiley \& Sons, Hoboken

xxxv. Joel D. Wisner, Keah-Choon Tan, G. Keong Leong. (2012). Principles of Supply Chain Management. (3 ${ }^{\text {rd }}$ ed.) SouthWestern Natorp Boulevard: Cengage Learning.

xxxvi. Kennedy, W. J., Wayne Patterson, J., \& Fredendall, L. D. (2002). An overview of recent literature on spare parts inventories. International Journal of Production Economics, 76(2), 201-215. https://doi.org/10.1016/S09255273(01)00174-8

xxxvii. Korpela,\&Tuominen. (1996). Inventory forecasting with a multiple criteria decision tool.Int. Journal of production economics V (45), P 159-168

xxxviii. Kothari, C.R. (2004) Research Methodology: Methods and Techniques. (2nd Edition). New Age International Publishers, New Delhi.

xxxix. Kotler, P. (2002). Social Marketing Improving the Quality of Life, (2 ${ }^{\text {nd }}$ ed.). Prentice-Hall, New Jersey Ltd., UK.

xl. Lai, K.H., Ngai, E.W.T. and Cheng, T.C.E. (2002). Measures for evaluating supply chain performance in transport logistics. Transportation Research, Part E: Logistics and Transportation Review, Vol. 38 No. 6, pp. 439-56.

xli. Lambert, D., Cooper, M. \&Pagh, J. (1998). Supply Chain Management: Implementation Issues and Research Opportunities. International Journal of Logistics Management, 9(2), pp. 1-19.

xlii. Madhani, Pankaj M.. (2017). Leveraging IT: Building a Customer-Focused Supply Chain strategy. Material Management Review, Vol. 14, No. 1, pp. 12-14, Available at SSRN: https://ssrn.com/abstract=3072860

xliii. Mendes, K., Karina, C., Pablo, C., \& Estevez, E. (2012). Information Sharing - Benefits on. 12(2), 49-55.

xliv. Mentzer, J. T. and Konrad, B. P. (1991). An efficiency/effectiveness approach to logistics performance analysis. Journal of Business Logistics, Vol. 12, No. 1, pp.33-62.

xlv. Michael, George C. (1979). Sales forecasting. Chicago, III : American Marketing Association

xlvi. Moberg, C. R., Cutler, B. D., Gross, A., \& Speh, T. W. (2002). Identifying antecedents of information exchange within supply chains. International Journal of Physical Distribution and Logistics Management, 32(9), 755-770. https://doi.org/10.1108/09600030210452431 
xlvii. Morlidge, S. (2014). Do forecasting methods reduce avoidable errors? Evidence from forecasting competitions. The International Journal of Applied Forecasting. Issue 32, 34-39.

xlviii. Neely, A., Gregory, M., \& Platts, K. (1995). Performance measurement system design: a literature review. International Journal of Operations \& Production Management, 15(4), 80-116.

xlix. Oluwaseyi, J. A., Onifade, M. K., \& Odeyinka, O. F. (2017). Evaluation of the Role of Inventory Management in Logistics Chain of an Organisation. LOGI - Scientific Journal on Transport and Logistics, 8(2), 1-11. https://doi.org/10.1515/logi-2017-0011

l. Patton, J. D. \&Feldmann, H. C., (1997). Service Parts Handbook. New York: The Solomon Press Publishers.

li. Paulraj, A., \& Chen, I. (2007). Strategic buyer-supplier relationships, information technology and external. Journal of Supply Chain Management, 2-15. http://www3.interscience.wiley.com/journal/118537084/abstract

lii. Pedagopu V. and MrMebratu M. (2018). The Current Scenario of Automotive Industry in Ethiopia. International Journal of Engineering, Science and Mathematics Vol. 8 Issue 1, January 2018. Pp 74-80

liii. Phung, 0J (2011). The impact of just-in-time inventory systems on small businesses. Journal of Accountancy, vol. 46. no. April

liv. Prajeesh, V. P., \& Sakthivel, N. (2016). Management of Equipment \& Machinery in Construction. Ijiset, 3(5), 113-118. www.ijiset.com

lv. Salcedo, S. and Grackin, A. (2000). 'The e-value chain.'Supply Chain Management Review, 3 (4): 63-70.

lvi. Saunders, M., Lewis, P. and Thornhill, A. (2007) Research Methods for Business Students. (4th Ed.). Financial Times Prentice Hall, Edinburgh Gate, Harlow.

lvii. Schnaars, S. P. (1984). Situational Factors Affecting Forecast Accuracy. Journal of Marketing Research, 21(3), 290. https://doi.org/10.2307/3151605

lviii. Seidmann, A., \& Sundararajan, A. (1998). Sharing Logistics Information Across Organizations: Technology, Competition and Contracting. Information Technology and Industrial Competitiveness, 107-136. https://doi.org/10.1007/978-1-4615-5485-1_7

lix. Shang, J. S., Li, S., \& Tadikamalla, P. (2004). Operational design of a supply chain system using the Taguchi method, response surface methodology, simulation, and optimization. International Journal of Production Research, 42(18), 3823-3849. https://doi.org/10.1080/00207540410001704050

lx. Sheikhi, M., Goodarzi, M., Nowrozinejad, A., \& Sheikhi, S. (2018). The role of information sharing on supply chain. Proceedings of the International Conference on Industrial Engineering and Operations Management, 2018(JUL), 181-188.

lxi. Simchi-Levi, D., Kaminsky, P., and Simchi-Levi, E. (2008). Designing and Managing the Supply Chain: Concepts, Strategies and Case Studies. $3^{\text {rd }}$ Edition, McGraw-Hill Irwin, Boston

lxii. Singh, S. (2014). Critical Skills for the Business Forecaster. Foresight, Winter(2014), 5-11.

lxiii. Skinner, Wickham (1974). The Focused Factory. Harvard Business Review 52(3):113 - 120 (May - June).

lxiv. Steven P. Schnaars. (1984). Situational Factors Affecting Forecast Accuracy. Journal of Marketing Research, Vol. XXI (August 1984), 290-7

lxv. Trapero, J. R., Fildes, R., \& Davydenko, A. (2011). Nonlinear identification of judgmental forecasts effects at SKU level. Journal of Forecasting, 30(5), 490-508. https://doi.org/10.1002/for.1184

lxvi. Tsadikovich, D., Levner, E., Tell, H., \& Werner, F. (2016). Integrated demand-responsive scheduling of maintenance and transportation operations in military supply chains. International Journal of Production Research, 54(19), 5798-5810. https://doi.org/10.1080/00207543.2016.1178864

lxvii. Vivek, N., Ravindran, S., Shalij, P.R. and Devadasan, S.R. (2009). Impact of information quality on the organizational performance in supply chain environment - an empirical study in India. Int. J. Indian Culture and Business Management, Vol. 2, No. 2, pp.111-124.

lxviii. Wagner, S., Jönke, R. \& A.B, E., (2012). A Strategic Framework for Spare Parts Logistics. California Management Review, 54(4), pp. 66-92.

lxix. Zhao, X., \& Xie, J. (2002). Forecasting errors and the value of information sharing in a supply chain. International Journal of Production Research, 40(2), 311-335. https://doi.org/10.1080/00207540110079121. 